\title{
On the Building of a Narrative
} The Ver Sacrum Ritual

\author{
Karin W. Tikkanen \\ University of Gothenburg, Dept. of Languages and Literatures \\ karin.tikkanen@sprak.gu.se
}

Received July 2015 | Accepted February 2016

\begin{abstract}
The ver sacrum ritual remains a riddle in the early history of the Apennine peninsula. Several ancient Roman as well as Greek sources use the ritual in explaining Samnite movements across the peninsula, as ritual group expulsion of settlers sent out to colonize new lands. In short, this becomes the narrative 'plot' of archaic colonization.

The ritual is however described very differently in the different sources, with regard to detail and to the plot elements involved in the tale. This article explores the various layers in the rendering of the ritual, and the different voices that take part in forming the ver sacrum narrative. With this perspective the ver sacrum becomes an expanded testimony of a tradition, used by different authors to stress various elements of their own historical reports.
\end{abstract}

\section{Keywords}

Ver sacrum - ancient religion - myth - Apennine peninsula - Samnites

\section{The Ver Sacrum Mystery}

The ver sacrum, the Roman grammarian Sextus Pompeius Festus tells us, was an ancient kind of vow practised by the early tribes on the Apennine peninsula. In a time of dire need, a tribe could consecrate the produce of an entire spring to a deity in exchange for liberation from their present calamity. Festus also gives one example of this, the case of the people of the Samnite chief Sthennius Mettius:

(C) KARIN W. TIKKANEN, 2016 | DOI 10.1163/1568525X-12342173

This is an open access article distributed under the terms of the Creative Commons Attribution 4.0 
When a damaging plague occurred in all Samnium, Sthennius Mettius, the chief of that people, when he had called a gathering of his fellow citizens, explained that in his sleep he had seen Apollo, who advised him that if they wanted to be free of this evil, they should vow a Sacred Spring - that is, that they should offer to him whatever was born the next spring. $(\text { Fest. } 15 \mathrm{OL})^{1}$

But the ritual apparently did not involve a mere regular animal sacrifice, for when 20 years had passed the plague returned:

When he was consulted again, Apollo replied that their vow had not been fulfilled, because the men had not been offered; but if they were to expel them they would certainly be free of the destruction. (Festus 150L) ${ }^{2}$

The imagery of the ver sacrum is one of the many enigmatic reflections from the early history of the Italian peninsula. Beginning with antiquarian comments in Varro and historical narratives in Livy, it is present in the accounts down to the first few centuries AD, in both Greek and Roman sources. As with most cases of ancient historical chronicles, or with historical chronicles in general, the fact that there are several sources dealing with one and the same event or topic also means that there are several different versions. When it comes to the ver sacrum narrative there are in fact no two versions that describe the ritual in exactly the same way, but the extant accounts are embellished with various substitute plot elements, differing from author to author. It is however striking, from the perspective of modern analysis, that the ancient references to the ritual are often mentioned in tandem, so that the ritual is treated as the sum content of all extant narratives taken together. This is the case in Eisenhut 1955, and in Heurgon's 1957 study, and also in the article in $\mathrm{OCD}^{3}$ (s.v. ver sacrum), as well as in Brill's New Pauly online (s.v. ver sacrum). In de Cazanove 1993, 262-263 all of the surviving aspects are equated in a summary table, as if the differing accounts in the various authors depended on mere selection or neglect. These narratives do, however, at a closer examination reveal a number of layers, not too transparent and at times also contradictory.

This article is an attempt to understand the various coatings added to the narrative of the ritual during the ancient period. With this perspective the ver sacrum becomes an expanding testimony of a tradition, embellished and

1 Translation by Smith and Cornell, in Cornell et al. 2013, vol. 2, 937. Unless otherwise stated, translations of classical texts are by the author of this article.

2 Translation by Smith and Cornell, in Cornell et al. 2013, vol. 2, 937. 
redecorated, as several authors in succession use it to stress different elements of their own historical reports.

Although more or less of the same date and age - the bulk of the narratives stem from a period ranging between approximately 80 в (Sisenna) and $24 \mathrm{AD}$ (Strabo) - the component units attributed to the ritual by the various authors are not at all the same, but intermingle and change from one account to the next.

In order to recognize the invention of the rite, and the ways in which its content and details change during the ancient period, the accounts in which the ceremony is treated are here listed, in chronological order, along with a short comment on the historical context and circumstances, where relevant, for the author in question. A discussion regarding the intertextuality of these passages will follow in sections 3 to 5 .

\subsection{8os Bc: Sisenna}

The oldest extant source to mention the ver sacrum ritual are the fragmentarily preserved Historiae, an account of the Social War written sometime near the beginning of the last century вс, by L. Cornelius Sisenna (са. 120-67 BC). There are only scant remnants of Sisenna's books, perhaps 23 in total (unless this is too high; see Badian 1966, 37 n. 140). What there is, mostly compiled in Nonius Marcellus' 3rd/4th century De compendiosa doctrina, seems to have been quoted primarily in order to preserve Sisenna's peculiar style. ${ }^{3}$ Rawson 1979, 335 suggests that Sisenna was a historian working on a grand scale, grouping events on geographic principles rather than chronological, but Briscoe considers him an annalist (see Cornell et al. 2013, vol. 1, 308; note also the discussion in Leeman 1963).

The earliest datable fragments by Sisenna relate to $91 \mathrm{BC}$, and it is likely that this was the starting point for his history, which probably continued until the death of Sulla in 78. Although dealing with contemporary events, Sisenna's work may also have included an account of earlier history, and the passages concerning the ver sacrum may come from a digression explaining the origin

3 Paradoxically enough, since Sisenna was apparently venerated as a great historian quite early on, and an important source for several later historians, there are only scant citations before that of Nonius (Chassignet 2004, XLIX). 
of the name of Bovianum (cf. Str. 5.250), thus Briscoe (see Cornell et al. 2013, vol. 3,411 .

... quod ${ }^{4}$ voto damnati fetum omnem dicuntur eius anni statim consecrare (Cornell F99; 100P)

... because, bound to fulfil the vow, they are said to have consecrated immediately the whole produce of that year ${ }^{5}$

...quondam Sabini feruntur vovisse, si res conmunis melioribus locis constitisset, se ver sacrum facturos (Cornell Fing; 99P)

... the Sabines are said at one time to have vowed that if their public situation had settled in a better position, they would perform a 'sacred spring'6

It must be noted that these two fragments come from two different citations in Nonius (p. 565, 12L and p. 840, $1 \mathrm{~L}$ respectively), and are thus not a continuous statement, although Nonius attributes them both to the fourth book of Sisenna's Historiae.

\section{$2.2 \quad 40 s-30 s$ BC: Varro}

The ver sacrum ritual is briefly mentioned by M. Terentius Varro (116-27 BC), although the passages preserved are merely fleeting remarks enveloped in lengthy narratives on other topics.

In the context of the observation that the Samnite and Sabine tongues must be somehow related, he speaks of a family connection between the two peoples, the latter having sprung from the former, ab Sabinis orti Samnites (L. 7.29). He also reveals that the Sabini had a habit of sending away their youth to found new colonies, in coloniam emittere volunt (R. 3.16.29). The last remark in particular is made in passing, in a description of the swarming of bees, and mentions practical reasons for the expulsion, multitudinem liberorum, 'too rich an offspring'.

None of these remarks are found in a historical context but are used on the one hand as an explanatory model for linguistic similitude, on the other as a metaphorical simile for an agricultural phenomenon.

\footnotetext{
4 Thus Chassignet 2004, 74f. Note that Peter (100P) emends quo for quod.

5 Translation by Briscoe, in Cornell et al. 2013, vol. 2, 651.

6 Translation by Briscoe, in Cornell et al. 2013, vol. 2, 659 .
} 
Although the ritual is not mentioned by name in either of these two references, they are still easily read as relating to the narrative tradition, and modern studies of the ritual often see fit to mention them for the sake of completion.

\subsection{2 os B : : Livy}

Appearing approximately a decade after Varro's De Re Rustica, Livy's account of the ver sacrum differs from all other sources pertaining to the rite. Livy ( $59 \mathrm{BC}-17 \mathrm{AD}$ ) is the only source listing a ver sacrum practice in Rome. This is in conjunction with the events of the years 217, 195 and 194 (in books 22, 33 and 34 , respectively).

After the disaster by the Trasimene lake in 217, Q. Fabius Maximus, on his first day of office when nominated dictator for the second time, gathered the senate to deliberate on the crisis: the Punic hostilities and the Gallic uprising in the Po Valley. Fabius Maximus recommended a prompt consultation of the Sibylline books, ${ }^{7}$ whereupon the decemvirs reported:

... that the vow ${ }^{8}$ which had been made to Mars on account of this war had not been duly performed, and must be performed afresh and on an ampler scale; that great games must be vowed to Jupiter, and temples to Venus Erycina and to Mens; and finally that a supplication and lectisternium must be celebrated in honour of the gods, and a Sacred Spring be vowed, if they proved victorious and the state remained as it had been before the outbreak of hostilities. (Liv. 22.9.6) ${ }^{9}$

The first three items on the list were to be completed immediately, but the fourth, the ver sacrum, was not achieved until 21 years later, in 195 BC (Liv. 33.44).

There are several aspects to consider regarding this Roman sacrifice. Livy calls the ritual a ver sacrum although this is much restrained in comparison with the Italic concept. The Roman pontifex maximus of 217, L. Cornelius Lentulus, voiced concern that the people must be asked whether they agree to submit to the ritual, and then proceeded to define the content of the 'produce' to be consecrated as quod ver attulerit ex suillo ovillo caprino bovillo grege 'whatever the spring shall produce from their flocks and herds, whether it be from swine or sheep or goats or cattle' (Liv. 22.10.3).

7 Cf. Liv. Per. 22.26 ob hanc cladem ex Sibyllinis libris ver sacrum votum.

8 There is no previous reference in Livy to such a vow.

9 Translation by Foster 1929, 231. 
Once performed, however, the ver sacrum of 195 was not considered complete, but Licinius, pontifex maximus of 194, deemed it necessary to perform the ceremony yet again (on this, see Briscoe 1981, 22-23). On both occasions, in 195 and 194, the items selected for sacrifice were clearly defined and limited to farm animals. In the second instance the specific period of 'spring' was also sharply delineated, as ver sacrum videri pecus quod natum esset inter kal. Mart. id. Mai 'animals born between the first day of March and the last day of April' (Liv. 34.44.3). ${ }^{10}$ Instead of a sacrifice to Mars (as in most of the Italic instances), the Romans aimed theirs at Jupiter (see further Heurgon 1957, 46).

\section{$2.4 \quad 20 s-10 s$ B : Dionysius of Halicarnassus}

The Greek narratives of the ritual add yet more detail, although none of these authors mentions a specific name for the ritual. In the first book of his Roman Antiquities, Dionysius of Halicarnassus (60-7 вС) gives us the background of Rome, starting with the first people known to have inhabited the area of the later city, the Aborigines, from whom the Romans are said to descend (Dionysius must have picked up the Latin word from a Roman source, e.g. Var. L. 5.53; Cic. Rep. 2.5; Sal. Cat. 6.1; Liv. 1.2.2).

Dionysius then proceeds to describe an old custom of these Aboriginals, to dedicate to a chosen god all the men born within a certain year, and, providing them with arms, to send them out as a 'sacred band of young men' to populate new land, 'according to a custom which I know many barbarians and Greeks have followed' (D.H. 16.1.1)." Dionysius then lists a number of possible reasons for such an expulsion, such as overpopulation, or crop failure caused by for example unseasonable weather changes:

If, indeed, this was done by way of thanksgiving for populousness or for victory in war, they would first offer the usual sacrifices and then send forth their colonies under happy auspices; but if, having incurred the wrath of Heaven, they were seeking deliverance from the evils that beset them, they would perform much the same ceremony, but sorrowfully and begging forgiveness of the youths they were sending away. (D.H. 16.1.2 $)^{12}$

10 Heurgon 1957, 47-48 argues that this limitation was chosen on purpose to limit the 'gross loss' of individuals and state to a bare minimum. In the pre-Julian calendar of 194, the two months in question, March and April, would have fallen between the beginning of December and the end of January in the solar calendar, and Licinius, as pontifex maximus, would have been very aware of this fact (see also discussion in Briscoe 1981, 22-23).

11 The origin of this theme may well be Varro, Dionysius' source for information on all things relating to Early Italy (cf. Gabba 1991, 115f.).

Translation by Cary 1937, 53 . 
The account of the process of emigration is embellished with more detail, with 'sacred bands' emanating out from a source community to found new settlements. Dionysius also adds the possibility of a celebration of a victory at war, thus offering very contrasting emotions in connection with the ritual: thanksgiving as opposed to suffering.

\section{$2.5 \quad$ 10s-20s AD: Strabo}

In his lengthy descriptions of all things Italian in book five of the Geographica, the Greek geographer Strabo (64/63 BC-24 AD) mentions all that he has gathered concerning the area, with tribes, myths and legends intertwined. There are statements of origin, such as that the Sabini are the oldest and most original people on the peninsula, from whom the Samnites originate (Str. 5.3.1), but Strabo also offers a long narrative concerning precisely how this 'originating' took place: the Sabines had been long at war with the Umbrians, and in order to end the hostilities made a vow- $\chi \alpha \theta \dot{\alpha} \pi \varepsilon \rho \tau \hat{\omega} \nu$ 'E $\lambda \lambda \eta \dot{\eta} \nu \omega \nu \tau i \nu \varepsilon$ s, 'common with some of the Grecian nations' - that they would consecrate to the gods the produce, $\tau \dot{\alpha} \gamma \varepsilon v o ́ \mu \varepsilon v \alpha$, meaning everything born or otherwise come into existence (animal or agricultural produce) of the year. ${ }^{13}$ They were victorious, and accordingly of the produce the one kind were sacrificed, the other consecrated.

Then a dearth ensued, and some one said that they ought to have dedicated the babies too; this they did, and devoted to Mars all the children born that year; and these children, when grown to manhood, they sent away as colonists, and a bull led the way. (Str. 5.4.12) $)^{14}$

In contrast with Dionysius' narrative of a general practice, Strabo tells of a specific event, a particular wartime occurrence, and a sacrifice embellished with the inclusion of children. Previous sources mention the expulsion of members from the tribe, though Strabo is the first to include these children as an element in the sacrifice itself, although transmuted into exile, as the children are allowed to grow into adulthood before being sent off. ${ }^{15}$

13 In the Latin sources the term used is ver 'spring', probably regulated to a defined period (specifically so in the Roman case). The Greek sources use the word हैं ‘ 'year'. According to Heurgon 1957, 9, the two labels can be understood to coincide: the produce of the spring was the produce, vegetal as well as animal, of the whole year.

14 Translation by Jones 1919, 465 .

15 In an article from 2000, de Cazanove hypothesizes that the comment 'the one kind were sacrificed, the other consecrated' (Str. 5.4.12) marks a differentiation between beasts and humans in that the former were sacrificed, the latter consecrated for expulsion at a later date (256f.). This must be mistaken, as is clear from the subsequent remark when 'some one' adds that 'they ought likewise to have consecrated the children'. Strabo must thus 


\subsection{2nd Century AD: Festus}

There remains scant information concerning S. Pompeius Festus today, but what there is suggests a period of activity in the 2nd century AD. His one extant book is an edited version of the non-extant De significatu verborum, compiled by the great polymath Marcus Verrius Flaccus in the late Augustan era (ca. 50 BC-20 AD). ${ }^{16}$ Verrius' work was a massive account in itself, but Festus did not merely copy this, but was critical in some places and may also have made small additions. ${ }^{17}$

Festus' work, in turn, is continued in the shape of an 8th century compilation made by Paulus Diaconus, at the Carolingian court. This epitome is not preserved in full but is transmitted in variously dented manuscripts probably from the gth and 1oth centuries onwards (see further Glinister et al. 2007, 109f.; on the composition of the epitome, esp. 122-124).

In the summary way of a grammarian, Verrius/Festus/Paulus writes: Ver sacrum vovendi mos fuit Italis 'the ver sacrum was a habit of the Italic tribes'. Then follows the content of the rite:

Magnis enim periculis adducti vovebant, quaecumque proximo vere nata essent apud se animalia immolaturos. Sed cum crudele videretur pueros ac puellas innocentes interficere, perductos in adultam aetatem velabant atque ita extra fines suos exigebant. (Fest. 519-520L)

For when restricted by times of great need they would vow that whatever living thing would be born among them the coming spring, they would sacrifice. But since they considered it cruel to kill innocent boys and girls, these where allowed to grow into adult age, and were then brought, with covered eyes, to the outer boundaries of the home village and sent away.

Parallel to the motif in Strabo, the potential sacrifice of human children (considered part of the fetum of a particular year, quaecumque vere proximo nata essent 'everything that would be born among them the following spring') is included as one of the rudimentary elements of the ritual. The major difference between the two sources is the origin of this thought: in Strabo it is an

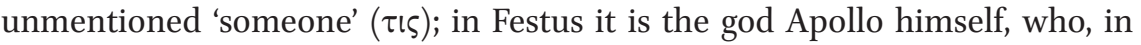
the story of the people of Sthennius Mettius, returns the plague 20 years after

\footnotetext{
be picturing a sacrifice that would, according to the initial plan, consist of vegetal and animal produce, with human children a later addendum only.

16 Cf. Kaster 1995, 19of.

17 On the construction of the lexicon, see Glinister et al. 2007, esp. Part 1. Lexicography and Scholarship.
} 
the initial assurance. This since, Apollo complains, humans had been excluded from the blood offering.

\subsection{The Later Sources}

In historical narratives contemporary with and postdating Festus, the ritual is mentioned in a somewhat altered shape, as a terminus technicus for almost any kind of migration.

Gaius Julius Solinus was a Latin grammarian and compiler and probably flourished in the late 2nd to early 3 rd century. The only work of his pen to survive is the De mirabilibus mundi, a deliberate mixture of knowledge with entertainment. Among several references to mythology there is a description of the fate of Catillus, the mythical founder of Tibur (Hor. Carm. 1.18.12; Sil. 4.225), after the slaughter at Thebes:

Catillus enim Amphiarai filius, post prodigialem patris apud Thebas interitum Oeclei avi jussu, cum omni foetu ver sacrum missus tres liberos in Italia procreavit, Tiburtum, Coram, Catillum ... (Solin. 2.8)

After the unnatural death of his father at Thebes, Catillus, son of Amphiaraus, on the command of his grandfather Oecles, was sent, with all his offspring, as a ver sacrum, and in Italy brought forth three children: Tiburtus, Choras, Catillus...

Not long after Solinus, we see a similar application in Marcus Iunian(i)us Iustinus' paragon on Pompeius Trogus, from the late 3rd or early 4th century:18

Namque Galli abundante multitudine, cum eos non caperent terrae, quae genuerant, CCC milia hominum ad sedes novas quaerendas velut ver sacrum miserunt. (Just. 24.4.1) ${ }^{19}$

For the Gauls, due to their abundant multitude, when the lands that had bred them could not keep them, sent 300,00o men to seek new lands, just like a ver sacrum.

In both tales the motif of civic stress is apparent: Catillus is one of few survivors of the bloodshed at Thebes, and the Gauls suffer from crude overpopulation.

18 The spelling of Iustinus' name remains uncertain. Cf. Neue Pauly, s.v. Iustinus, M. Iunia$n(i)$ us I., and Lexikon des Mittelalters, s.v.Justinus, 2. J.

19 On the proximity between the rendering of the Gallic migration of the 4th century BC in Iustinus/Trogus, and that in Livy (Liv. 5.34.2), see e.g. Legnani 1994, 65 f. 
In both of these narratives the migration takes place (as in Varro and Dionysius) due to mere practical necessities.

In Solinus, Catillus himself is described as fulfilling the role of a ver sacrum. In Iustinus, the short word velut 'just as' suggests the transformation from a (potentially) real ritual into a formalized exodus. One may however note that Solinus, a few lines before the cited passage, quotes Cato speaking of the same Catillus. Cato may thus have been the source also for Solinus' summary use of the ver sacrum image.

\section{3}

\section{Historicity}

Several of the sources refer to the Sabines as the origin of several of the other early tribes on the peninsula, and elements of the ritual are used to explain the names later given to the new settlements. The practice is stated to have originated among the Sabines, who gave birth to the Samnites (Var. L. 29), as well as the Picentes (Str. 5.4.2; Plin. Nat. 3.110). The Samnites in turn sent out youths to populate the lands in the south, who, having become the Lucani, in their turn brought forth the Bruttii (Str. 5.3.1). ${ }^{20}$ In Strabo's tale of the Samnites the selected children were led by a bull, bos, and founded the city of Bovianum (Str. 5.4.12); there are other references stating that the Hirpini and the Lucani were guided by a hirpos and a lucos, in their respective tongues the word for 'wolf' (Str. 5.4.12; Fest. 93L), and that the future Picentes were guided by a picus, a woodpecker (Str. 5.4.2; Plin. Nat. 3.110). ${ }^{21}$

Linguistically speaking, the various languages attested in the regions attributed to these tribes show enough correspondences to be grouped together as the Sabellic language group. ${ }^{22}$ Notably, however, the ritual is never mentioned in reference to the Umbrians, the Sabellic tribe that inhabited the area around the city of Iguvium (mod. Gubbio) and who, according to legend, were among the oldest races of Italy (D.H. 1.19.1; Plin. Nat. 3.112.13).

There is, further, no literary or iconographic evidence of the ver sacrum in any of the areas where the ritual is said to have taken place. The ritual can therefore also be viewed as mere legendary, etiological fiction, summed up

\footnotetext{
$20 \quad$ For a summary of all these elements, see Eisenhut 1955, 919-922.

21 Cf. the story of how vitulus 'calf' came to be used as the name of the whole state, Italia (D.H. 1.35.2), see De Sanctis 1956, 209f.; Heurgon 1957, 8; Briquel 1984, 94.

22 On the use of this modern label in relation to the older 'Osco-Umbrian languages', see Rix 2002, if. For the application of the labels Sabini and Sabelli by the ancients, see Salmon 1967, 32; Dench 1995, 103-107.
} 
from the perspective of the late Republic. In the late Republican era the events leading up to the upheavals of the Social War would have still been fresh in the minds of most Romans. Also, as a consequence of the Romanization process of the last century $\mathrm{BC}$, there was the voluntary migration for the purpose of business, leading to the intermingling in Rome of people from all over the peninsula. This would have reminded a literary audience of the disparity and the multilingual history of the peninsula (see for example Liv. 1.18). From this perspective the ver sacrum is a package account for the diversity among tribes who, on the surface, resembled each other enough to speak similar and perhaps mutually intelligible languages, but who were not connected to each other in any larger political federation or state, apart from under pressure from Rome. Heurgon 1957, 51 calls the ritual mere "rétrospective et légendaire", and Dench takes a similar approach (see Dench 1995, 183; 1997). The creation of such legends must in any case be later than the establishment of the separate state entities, and cannot be said to be contemporary with the supposed prehistoric migrations (Bispham 2007, 181).

In outspoken defence of the historicity of the ritual, other scholars stress historical references from the last century BC, such as for example Livy's description of 217, 195 and 194 (de Cazanove 1993, 24). Salmon 1967, 35 considers Sisenna's references certain proof of the historicity of the ritual as practised during the Social War, since the initial quondam of Sisenna's paragraph could also be translated 'at certain times', rather than 'at one time'. Rawson 1979, 337 is not convinced, and believes that Sisenna's is a mere antiquarian remark rather than a comment on concurrent practices.

The strongest support in favour of the authenticity of the ritual is found in Festus. In his account of Sthennius Mettius and the Mamertini, Festus says that the group ended up going south, eventually taking part in the battle of Messane (mod. Messina). This coincides with other sources that mention groups of Campanian mercenaries in Sicily, and what appears to be the same band of Samnite fighters shows up in the employ of Agathocles, the tyrant of Syracuse, in 315 BC (Plb. 1.7.2; D.s. 21.18). ${ }^{23}$ Later on these Samnites took control over the city itself, in Festus by invitation (Fest. 15oL), according to Polybius and Diodorus by hostile takeover (Plb. 1.7.2; D.s. 21.18; see further de Cazanove 2007, 47). Although not described as such, the massive migration of some 4000 Samnite and Paelignian families to Fregellae in 178 вС (Liv. 41.8.8) may also have had something to do with a ver sacrum (see discussion in de Cazanove 2000, 261; Smith and Cornell, in Cornell et al. 2013, vol. 3, 568-570).

23 On Samnite paid soldiers in accounts of the 4th and 3 rd centuries BC, see Hannah and Hannah 1990, 275-279. 
Whether or not an actively remembered ritual, the model of the later narrative tallies, at least on the surface, with historical movements in the early history of the peninsula. The movement motif is also the element that is taken up in the later re-use of the ver sacrum formula (see section 2.8).

\section{Dionysius and the Pelasgians}

Considering the sources as laid out in the preceding sections, the ver sacrum narrative of Festus appears strikingly different in terms of composition. The practice of the Mamertini (section 1), although labelled a ver sacrum, contains two major narrative differences in relation to the other sources.

The first is the element of human sacrifice. The expulsion of 'sacred bands of youth' to populate and colonize new land is included, either by implication or overtly stated, in all accounts except for Sisenna and Livy. The Sisenna extract features the sacrifice of a fetum omnem, an unspecified 'produce', which could be taken to mean either vegetal produce ( $T L L$ s.v. fetum II. A.2, 6.1.638.55) or animal offspring (ibid. A.1.c, 6.1.637.50), but equally also human offspring (ibid. A.1.b, 6.1.637.5). Livy on the other hand specifies the content of the sacrifice of the year 195 BC as limited to animals (see section 2.3). ${ }^{24}$

In contrast, the programmatic expulsion of a group of new settlers is alluded to by Varro and Pliny, and overtly mentioned by Dionysius, neither alluding to a ritual sacrifice. Varro and Dionysius both treat the expulsion as a practicality rather than the result of a situation of civic stress. In these sources, the reason given is that of overpopulation. However, as Forsythe 2006, 189 remarks, an immediate problem of overpopulation cannot be solved in this way, since some 15 or 20 years are required for the children to grow into maturity. Rather, the ver sacrum selection must have been used fairly regularly over several generations, so as to avoid too populous habitations in agriculturally poor areas (see for example Eckstein 2006, 139). If so, the expellendi were probably chosen from among the young adults. In terms of the emigrating individuals, this would have been just as grave for their own wellbeing; as stated by de Cazanove 2002, 264 the expulsion once performed would be irreversible, just like death.

24 Heurgon considers the fact that several new Roman colonies were founded in 195/194, e.g. Volturnum, Liternum, and Puteoli, all in regions where the mythical rite had first been in use. There is, however, no indication in Livy that this was in any case interconnected, and it is perhaps also a mere coincidence that the ritual of 195 took place 21 years after the vow, parallel to the notion of consecrated newborns brought up to adult age (Heurgon 1957, 39). 
In Strabo and Festus the motif is different, and the expulsion is mentioned as a result of the sacrificial process, meaning the primary vow and the subsequent consecration of produce of the selected period. In Strabo the ritual expulsion is explained as the result of a substitutive act through which the children who should perhaps be included in the sacrifice are to be expelled from the home community. ${ }^{25}$ In the tale of the Mamertini as narrated by Festus, the inclusion of human children in the sacrifice is instead an overt divine request, mitigated by an allowed substitution in the form of expulsion.

The second feature in which Festus' account differs from the others is that of the order of events. In Sisenna, Livy and Strabo, the ver sacrum ritual begins with a vow of consecration. The sacrifice itself, however, does not take place until relief from the concurrent calamity has been delivered. In Festus' Mamertine narrative the people ask an oracle for advice, and receive an answer that they interpret to the best of their abilities, taking 'yearly produce' to mean animal offspring only. They then proceed to a more or less immediate sacrifice, after which they are given a 20 years' respite. When the plague returns they are told that their sacrifice was faulty, and that the sum due to the god has not been completed.

In order to explain this aspect of Festus one needs to turn to Dionysius. Both Dionysius and Strabo reflect on the habit of sending out children in order to colonize new land as a custom they know of as 'Greek' (Str. 5.4.12; D.H. 1.16.1). Strabo (6.1.6) tells of the Chalcidians, who dedicated one man in ten to Apollo and sent them to Delphi; these men later on founded Rhegium. ${ }^{26}$ Dionysius, on the other hand, provides us with the tale of the Pelasgians.

The Pelasgians, Dionysius tells us, first lived in Thessaly, but were for some reason forced to leave, and settled among the Aborigines in Latium. Although at first happy, the Pelasgians eventually fell into calamity as a great drought set upon the land, causing fruit and corn to die, and many unusual diseases also hit the land. All this, we are told, because of the incomplete status of a promise made years before: an oracle informs them that the source of the god's wrath is the exclusion of human offspring, 'a thing of all others the most precious in the sight of the gods'. In a time of scarcity the Pelasgians had vowed to offer to

25 For a discussion on the substitution of dolls for human sacrifices in ancient Rome, e.g. the Mania dolls of the Lares festival and the Argei traditions, see Prescendi 2007, esp. 171-188; on the Argei figures, see D.H. 1.38.2; and further Frazer 1931, 425-429. On the use of animals as replacement for humans, see Capdeville 1971.

26 On the discrepancies between Gr. $\delta \varepsilon x \alpha \dot{\tau} \eta$ and the Italic ritual, see Heurgon 1957; Malkin 1987, 39. For a positive comparison, see Versnel 1993, 307-308. 
the gods tithes of their future increase, but in the end set apart and offered to the gods the promised portion of all their fruits and cattle only (D.H. 1.23-24). ${ }^{27}$

There are evident parallels between Dionysius' Pelasgians and Festus' Mamertini. Both tales contain the elements of civic stress, the immediate sacrifice of yearly produce, and also the same interpretation of the requested 'yearly produce'. As calamity strikes anew, both tribes are notified that this is a direct consequence of their interpretation, with human children left out of the sum total due to the god. The ultimate decision of the Pelasgians is not wholly clear, though the final word from the oracle is followed by strife and

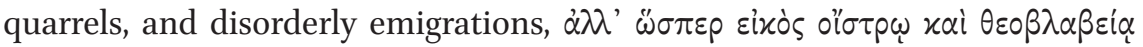
$\dot{\alpha} \pi \varepsilon \lambda \alpha u v o ́ \mu \varepsilon v \alpha l$, 'such as might well be expected from a people driven forth by a frenzy and madness inflicted by the hand of heaven' (D.H. 1.24.3), evident unrest which suggests a cruel fate.

\section{5}

\section{Sources}

The programmatic make-up of the ver sacrum ritual can thus be differentiated into layers. The earliest accounts of the ver sacrum that survive to our days were probably based on information provided by yet older authors, that may still have been available in their entirety to the historians of the late Republican era (Cornell 2004, 116-118). As already mentioned, most of the extant sources pertaining to the ver sacrum stem from roughly the same period, from the 80 s BC down to the early first century AD, and also differ to quite an extent. On the one hand this reflects the content of the sources available to the individual author and the differing levels of 'exactness' in the transmission of historical data (see e.g. Brunt 1980). On the other hand the various items selected for inclusion mirror the individual choices made by each author in the creation of a discrete narrative.

The main feature pertaining to the ritual, and the narrative ingredient seen in the majority of the ver sacrum sources, is that of reoccurring Sabine/Samnite emigration. This is the one element to appear in all of the narratives interpreted as describing the ver sacrum, in greater or lesser detail, and one which is additionally alluded to by other historical references. All other elements - the vow in a moment of civic stress (alternatively due to population growth, or by

27 Dionysius also comments (D.H. 1.23.5) that the historian Myrsilus of Lesbos recounts the same succession of events in relation to the Tyrrhenians, due to an ancient 'mix-up' of the two names (D.H. 1.23.5; see also D.H. 1.25 and 1.29). On this as an intentional substitution of protagonists on behalf of Dionysius, see Gabba 1975, esp. 43-45. 
way of thanksgiving), and the sacrifice of produce from a pre-defined period, and so on-are narrative ingredients that can be included, embellished or left out according to the intentions of each individual author.

The narrative plot element that makes the account as preserved by Festus stand out from all of the others, is the feature of a god interceding in the acts of the humans. ${ }^{28}$ This topos is not included in any other of the preserved Latin sources, but seems particular to the Greeks. This is also in line with a further differentiation to be made between the sources, in that the Latin authors (i.e. Sisenna, Varro, Livy, Festus) refer to a perceived historical reality, whereas the Greek authors mention narratives set in a mythical period.

The element of divine intervention in human affairs is reminiscent of Greek legends, in particular the foundation legends of Greek colonies. Foundation legends are etiological constructions that function as justifications for power structures and territorial claims. As such, they are extremely useful, especially for younger communities, in providing a sense of existential assertion and historical longevity. At the same time, such legends can also spread to neighbouring communities (Bickerman 1952).

In this context it is worth noting that in the compiled text of Festus, the ver sacrum is mentioned not once but twice; under the name given to the tribe of Sthennius Mettius, Mamertini (Fest. 150L; see section 1), and then again under a separate heading towards the end of the book (Fest. 519-520L; see section 2.7). The second section is the simple description of the ritual, with no reference to a source, but the first instance is completed with a reference to a certain Alfius, and the first book of his Bellum Carthaginiense.

Very little is known concerning this Alfius, but Cichorius 1922, 59 sets the date for his birth to no later than 40/30 BC, and argues that Alfius was a contemporary of Verrius. ${ }^{29}$ Smith and Cornell leave the question open, concluding only that Alfus was "earlier" than Verrius (Cornell et al. 2013, vol. 1, 488).

However one choses to date him, it remains certain that Alfius was sympathetic towards the Mamertines, and as shown by Cichorius, he was even possibly an Oscan descendant himself (Cichorius 1922, 61f.). Alfius' version of the ver sacrum ritual, summarized and continued in Verrius/Festus, may thus have struck close to a potential Samnite rendering. This version appears to have become subsumed into a wider web of legendary foundation histories carrying several overtones referring to Greek tradition, potentially the result of

28 In most of the Italic references the god in question was Mars; on the role of Apollo in the narrative of Sthennius Mettius reflecting a process of Hellenization, see Smith and Cornell, in Cornell et al. 2013, vol. 3, 569 .

29 On the identification of Alfius, see Cichorius 1922, 58-67; Farney 2007, 222-223, esp. n. 148. 
the close exchange of transcultural images and values as seen in the area of the Bay of Naples in the early centuries of Greek colonisation (cf. discussion of the 'Middle Ground' concept in Malkin 2002).

The Roman authors, writing towards the end of the Republic, either did not know of the Greek element of divine intervention in the legend, or did not find it valuable enough to be included in their own narratives. The comments made by Dionysious and Strabo, that the ritual expulsion of the Samnite tribes was similar to a custom they knew of as Greek, provide a supporting explanatory setting for what they perceived to be the potential source for this motif, and also signal the reason for the inclusion of the tale in their own renderings, namely a familiarity with the topos that could be explained through references to a Greek cultural framework.

\section{Conclusion}

The ver sacrum ritual follows the narrative plot pattern of archaic colonization: a moment of civic stress prompts the consultation of an oracle or god, which in turn authorizes the foundation of a new colony. Movement as such is well integrated in the social history of the peninsula (de Cazanove 1993, 2of.), and there seems to be a certain amount of collaborative historical basis in tales of emigration among the Samnite tribes for the ver sacrum to function as an explanatory motif, even though these narratives probably arose at a much later stage in time.

Most of the Latin sources mention the name of the ritual, ver sacrum, in the context of a historical reality, with differing levels of exactitude in the additional plot elements. The Greek sources discuss a ritual they know of as legendary, with elements of divine intervention similar to other Greek narratives, features that also became subsumed into the tale as known to Alfius.

The modern treatment of the ver sacrum narrative involves combining the different version of the tale into one summary table. This article has shown how these differences may have arisen, as choices made by the single authors based on their own judgements and selection. As Bell 1992, 118 shows, a ritual is not by necessity a singular custom but rather a collection of variable performances, and the perception of a 'tradition' consists of equal parts continuity and change. The narratives of the ver sacrum ritual are best understood as a collection of various accounts from different regions, and from different population groups, most likely with varying recollections and different attributions to the liturgy. 
The ver sacrum ritual of Old Italy was perceived as a tradition, and the different narratives served to explain both the memory of perceived migrations across the peninsula, and the interrelations between the different Samnite tribes and their respective histories, totems, and territorial claims. Although some scholars (e.g. Lancel 1998, 98) imply that the plot element of a divine request for human blood was a primary component of the ritual, there is really nothing corroborating this theory (see Caro Roldán 2000), irrespective of whether or not one ascribes the ritual a historical value. This was rather a Greek legendary element that was absorbed into one strand of the narrative tradition, represented by the Alfius/Verrius/Festus version and also alluded to by Strabo.

The question, at the end, is not one of defining "the Original Ritual", not wie es eigentlich gewesen. In the words of Grandazzi, "although the Truth is no longer with us, it does exist somewhere, even if we do not know where exactly" (Grandazzi 1990, 65). What one can discuss is the nature of this perceived Truth, and the singularity or plurality of its mould. ${ }^{30}$

\section{Bibliography}

Badian, E. 1966. The Early Historians, in: Dorey, T.A. (ed.) The Latin Historians (New York), 1-38

Bell, C. 1992. Ritual Theory, Ritual Practice (New York)

Bickerman, E.J. 1952. Origines Gentium, CPh 47, 65-81

Bispham, E. 2007. The Samnites, in: Bradley, G. et al. (eds.) Ancient Italy. Regions without Boundaries (Exeter), 179-223

Briquel, D. 1984. Les Pélasges en Italie. Recherches sur l'histoire de la légende (Rome)

Briscoe, J. 1981. A Commentary on Livy. Books xxxiv-xxxvii (Oxford)

Brunt, P.A. 1980. On Historical Fragments and Epitomes, CQ 30, 477-494

Capdeville, G. 1971. Substition de victimes dans les sacrifices d'animaux à Rome, ME FRA $83,283-323$

Caro Roldán, J.M. 2000. Una aproximación a la naturaleza del uer sacrum, Gerion 18, 159-19o

30 Sections of this paper were presented at the Latin Seminar at the University of Gothenburg, and I thank my colleagues there for all their helpful comments, in particular Prof. Gunhild Vidén and PhD Anna Blennow. The final revision work on this article was made possible through a research grant from the Department of Linguistics and Philology, Uppsala University. 
Cary, E. 1937. Dionysius of Halicarnassus. Roman Antiquities. Vol. 1. Books 1-2 (Harvard) de Cazanove, O. 1993. La penisola italiana prima della conquista romana, in: Vauchez, A. (ed.) Storia dell'Italia religiosa. Vol. 1. L'antichità e il medioevo (Rome), 9-39

de Cazanove, O. 2000. Sacrificer les bêtes, consacrer les homme. Le printemps sacré italique, in: Verger, S. (ed.) Rites et espaces en pays celte et méditerranéen. Étude comparée à partir du santuaire d'Acy-Romance (Rome), 253-276

de Cazanove, O. 2007. Pre-Roman Italy, Before and Under the Romans, in: Rüpke, J. (ed.) A Companion to Roman Religion (Malden), 43-56

Chassignet, M.2004.L'annalistique Romain. Vol.3.L'annalistiquerécente. L'autobographie politique (fragments) (Paris)

Cichorius, C. 1922. Römische Studien. Historisches, Epigraphisches, Literaturgeschichtliches aus vier Jahrhunderten Roms (Leipzig)

Cornell, T.J. 2004. Deconstructing the Samnite Wars. An Essay in Historiography, in: Jones, H. (ed.) Samnium. Settlement and Cultural Exchange (Providence), 115-131

Cornell, T.J. et al. 2013 (eds.) Fragments of the Roman Historians. Vols 1-3 (Oxford)

De Sanctis, G. 1956. ${ }^{2}$ Storia deiromani. Vol. 1. La conquista del primato in Italia (Florence)

Dench, E. 1995. From Barbarians to New Men. Greek, Roman, and Modern Perceptions of Peoples of the Central Apennines (Oxford)

Dench, E. 1997. Sacred Springs to the Social War. Myths of Origin and the Question of Identity in the Central Apennines, in: Cornell, T., Lomas, K. (eds.) Gender and Ethnicity in Ancient Italy (London), 43-51

Eckstein, A.M. 2006. Mediterranean Anarchy, Interstate War, and the Rise of Rome (Berkeley)

Eisenhut, W. 1955. Ver Sacrum, RE 2. Reihe, 15, 911-923

Farney, G.D. 2007. Ethnic Identity and Aristocratic Competition in Republican Rome (Cambridge)

Forsythe, G. 2006. A Critical History of Early Rome. From Prehistory to the First Punic War (Berkeley)

Foster, B.O. 1929. Livy. History of Rome. Vol. 5. Books 21-22 (Harvard)

Frazer, J.G. $1931{ }^{4}$ Ovid. Fasti (Cambridge, MA)

Gabba, E. 1975. Mirsilio di Metimna, Dionigi e i tirreni, RAL 30, 35-49

Gabba, E. 1991. Dionysius and the History of Archaic Rome (Berkeley)

Glinister, F. et al. 2007. Verrius, Festus, and Paul. Lexicography, Scholarship, and Society, (London)

Grandazzi, A. 1990. The Future of the Past. From the History of Historiography to Historiology, Diogenes 38, 51-74

Hannah, P., Hannah, R. 1990. Athens-Sicily-Campania. Warriors and Painters, in: Descœudres, J-P. (ed.) Greek Colonists and Native Populations (Oxford), 267-279

Heurgon, J. 1957. Trois études sur le 'ver sacrum', Latomus 26 
Jones, H.L. 1919. Strabo. Geography. Vol. 2. Books 3-5 (Harvard)

Kaster, R.A. 1995. Suetonius. De grammaticis et rhetoribus (Oxford)

Lancel, S. 1998. Hannibal (Oxford)

Leeman, A.D. 1963. Orationis Ratio (Amsterdam)

Legnani, A. 1994. La presunta invasione celtica del VI sec. a. c. in: Sordi, M. (ed.) Emigrazione e immigrazione nel mondo antico (Milano), 55-68

Malkin, I. 1987. Religion and Colonization in Ancient Greece (Leiden)

Malkin, I. 2002. A Colonial Middle Ground. Greek, Etruscan, and Local Elites in the Bay of Naples, in: Lyons, C.L., Papadopoulos, J.K. (eds.) The Archaeology of Colonialism (Los Angeles), 151-181

Prescendi, F. 2007. Décrire et comprendre le sacrifice (Stuttgart)

Rawson, E. 1979. L. Cornelius Sisenna and the Early First Century BC, CQ 29, 327-346

Rix, H. 2002. Sabellische Texte. Die Texte des Oskischen, Umbrischen und Südpikenischen (Heidelberg)

Salmon, E.T. 1967. Samnium and the Samnites (Cambridge)

Versnel, H.S. 1993. Inconsistencies in Greek and Roman Religion. Vol. 2. Transition and Reversal in Myth and Ritual (Leiden) 